\title{
Evaluation of the Electrodialysis Process for the Treatment of Metal Finishing Wastewater
}

\author{
Roni F. Dalla Costa , Cláudia W. Klein, Andrea M. Bernardes and Jane Zoppas Ferreira* \\ LACOR, PPGEM, Universidade Federal do Rio Grande do Sul, Av. Osvaldo Aranha, 99/706, 90035-190 \\ Porto Alegre - RS, Brazil
}

\begin{abstract}
Neste trabalho estudou-se o tratamento, por eletrodiálise, de um efluente alcalino, oriundo de um processo de galvanoplastia, contendo íons de $\mathrm{Zn}, \mathrm{Ni}, \mathrm{Cu}, \mathrm{Fe}$ e Al, bem como de $\mathrm{Na}$ e $\mathrm{CN}^{-}$. O estudo foi feito tanto em células de bancada quanto em uma planta piloto, utilizando-se membranas íonseletivas Nafion e Selemion. Os resultados mostraram que os íons metálicos apresentam, em sua maioria, caráter aniônico devido à formação de complexos de coordenação. Cada tipo de íon metálico apresentou uma diferente taxa de extração da solução tratada, dependendo do controle do processo ser potenciostático ou galvanostático. Para $\mathrm{Zn}, \mathrm{Ni}$ e $\mathrm{Cu}$ houve maior extração sob controle galvanostático. Já para o Al foi verificado uma maior remoção do efluente quando o controle era potenciostático. Observou-se um comportamento anômalo para os íons ferro, os quais não são removidos do mesmo modo que os demais íons metálicos. O rendimento da extração foi máximo em tempos de ensaio relativamente baixos (2-3 h).
\end{abstract}

Metal finishing wastewater containing ions of $\mathrm{Zn}, \mathrm{Ni}, \mathrm{Cu}, \mathrm{Fe}$ and $\mathrm{Al}$, as well as of $\mathrm{Na}$ and $\mathrm{CN}^{-}$ in alkaline $\mathrm{pH}$ was treated by electrodialysis. The treatment was conducted in a laboratory cell and in a pilot plant unity. The experiments were carried out using Nafion and Selemion membranes. Results showed most of the metallic ions to have an anionic nature, due to the formation of coordination complexes. Each metallic ion showed a different rate of extraction from the treated solution, depending on the galvanostatic or potentiostatic operation mode. $\mathrm{Zn}, \mathrm{Ni}$ and $\mathrm{Cu}$ have shown higher extraction under galvanostatic control. For $\mathrm{Al}$, higher extraction was observed when the experiment was conducted in a potentiostatic mode. Fe ions exhibited an unexpected behavior, not being removed in the same way as the other ions. The best extraction results were obtained within $2-3 \mathrm{~h}$ of treatment.

Keywords: electrodialysis, wastewater treatment, metal finishing wastewater, membranes

\section{Introduction}

In recent years, there has been a surge of scientific interest in the treatment of metal finishing wastewater, in particular, the substitution of conventional hazardous processes with new benign environmental processes. ${ }^{1}$ However, changing some aspects of metal finishing processes falls into problems related to technical limitations and economical constraints. Furthermore, there is a need to adequately manage and recycle the contaminated wastewater. Traditional galvanic wastewater treatment systems reduce the toxicity of the wastewater by employing chemical processes to coagulate, flocculate, and settle out the solid wastes for off-site disposal. Ultimately, the treated wastewater can be discharged to the environment within concentrations allowed by local

\footnotetext{
* e-mail: cafjzf@ vortex.ufrgs.br

\# Present address: PPGEAM, ULBRA, Rua Miguel Tostes, 101, 92420-280 Canoas - RS, Brazil
}

legislation. This approach uses large amounts of chemicals, produces large volumes of solid waste for disposal, and does not recover process solution. ${ }^{2}$

Electrodialysis is an alternative process in the treatment of wastewater, since it allows the re-use of process water and the recovery of metal ions, minimizing or even avoiding the production of galvanic sludge. Electrodialysis employs a membrane separation technique where ions are transported through ion selective barriers from one solution to another using an electric field as the driving force. ${ }^{3}$ In an electrodialysis stack, as shown in Figure 1, cation and anion selective membranes are alternately arranged in a filter press-like system to form dilute and concentrated flows between the membranes. The electrodes, placed in the extremities of the stack, are in contact with an electrode rinse solution. The applied direct current (dc) electric field produces the transportation of the cations towards the cathode and the anions towards the anode. During this transportation anions are able to permeate through anion-selective membranes, but are 
blocked by the cation-selective membranes. The opposite occurs with cations. As a result, two different solutions are produced inside the stack: one more dilute (the diluate) and the other more concentrated (the concentrate) than the feeding solution.

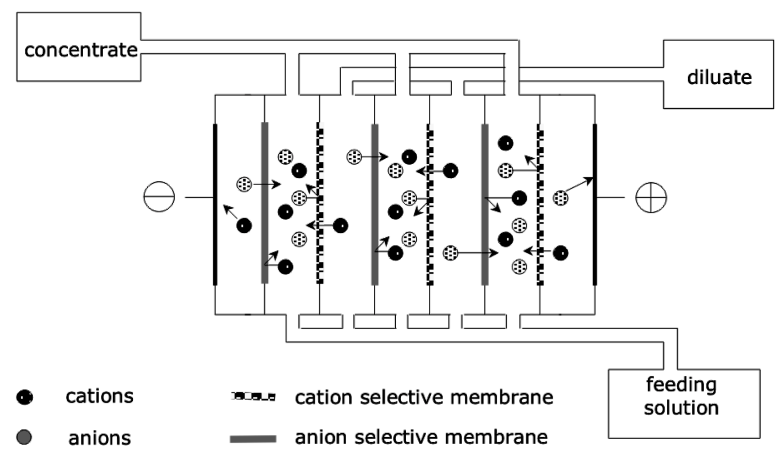

Figure 1. Principle of the electrodialysis technique.

The use of electrodialysis for pollution prevention in industrial processes has been suggested in the literature. ${ }^{4}$ In galvanic industry, electrodialysis can be used for regenerating the metal finishing baths and wastewater treatment. ${ }^{3,5} \mathrm{It}$ is of particular interest to recycle the rinse water as a diluate and the metal ions as a concentrated brine, which can be used to recompose the plating bath. However, technical problems with the process need to be completely understood. The process is geared to accomplish the reduction of solid and wastewater disposal costs, the reduction of raw material consumption (including water), the maintenance of consistent quality of plating baths, and the increase of plating rates. The main technical limitations to achieving these goals are: organic contamination of the wastewater which can damage electrodialysis membranes, inadequate concentration of metal ions in the rinse water under treatment, inorganic contaminants that can accumulate in the recycled streams, and eventually excessive energy consumption due to low electrical efficiency.

There is a current need to evaluate the use of electrodialysis on the treatment of wastewater with the aim of scaling it up to industrial operation. However, it is important to understand the behavior of such a system either in laboratory or pilot plant conditions. In this work, the treatment of wastewater samples from a zinc-cyanide chemical plating process that is used to produce a metallicalloy surface finishing was evaluated. This study was carried out in a laboratory electrodialysis cell and in a pilot electrodialysis plant. Since the treated wastewater is highly alkaline $(\mathrm{pH}>12)$ and contains various metallic ions and cyanide, most of the metallic ions are assumed to be present as coordinated complex ions, which can have a negative charge. Hence, these are transported through anion-selective membranes instead of cation-selective membranes. From the experiments carried out in the laboratory it was possible to determine the nature of the ions in the solution, while the tests conducted in the pilot plant showed the general behavior of the treatment by electrodialysis.

An important parameter used to evaluate the efficiency of the electrodialysis process is the percent extraction, defined as:

percent extraction $=\frac{\left(c_{0}-c_{f}\right)}{c_{0}} \times 100$

where $c_{0}$ is the ion concentration in the diluate in the beginning of the experiment and $c_{f}$ is the ion concentration in the diluate at the end of the experiment.

\section{Experimental}

\section{Materials}

Alkaline solutions were prepared from distilled water and $\mathrm{NaOH}$. Random samples were obtained directly from wastewater produced in an industrial chemical plating process. The cation-selective and anion-selective membranes used in the laboratory electrodialysis cell were Nafion 450 (Nafion is a registered trademark of E. I. du Pont de Nemours and Co.) and Selemion AMP (Selemion is a registered trademark of Asahi Glass Co.), respectively. Pilot plant tests were carried out in a Tecnoimpianti I - TI 1624 electrodialyzer, using Selemion CMV and Selemion AMV as cation-selective and anion-selective membranes, respectively.

The laboratory electrodialysis cell containing five compartments, shown in Figure 2, was manufactured in transparent acrylic. The solutions were pumped at a flow

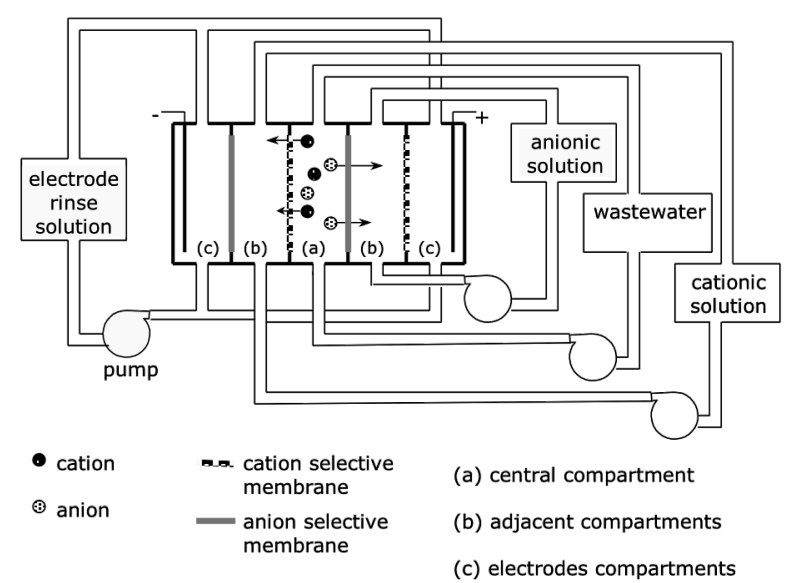

Figure 2. Five-compartment laboratory electrodialysis cell scheme. 
rate of $220 \mathrm{~mL} \mathrm{~min}^{-1}$ by means of a diaphragm pump from a reservoir to the cell and from the cell back to the reservoir in a closed loop. The cathode was a stainless steel foil and the anode was a platinum sheet, both having the same area as the membrane $\left(14.5 \mathrm{~cm}^{2}\right)$. A direct current supply was employed in all the experiments.

The pilot plant electrodialyzer was equipped with a stack containing 5 membrane pairs with an effective area of $172 \mathrm{~cm}^{2}$ per membrane. The stack anode was platinized titanium and the cathode was stainless steel. The equipment operated both in potentiostatic and galvanostatic modes and allowed on-line monitoring of the conductivity, $\mathrm{pH}$ and temperature of the solutions, as well as the total current and voltage of the system.

\section{Methods}

Prior to carrying out the experimental work, the wastewater samples were characterized by atomic absorption spectroscopy (AAS) and inductively coupled plasma spectroscopy (ICP) for the metallic ions. The main focus of this initial work was to better understand the variation of the wastewater composition. Hence, in four hours intervals, samples were taken directly from the process in a total period of $108 \mathrm{~h}$ and characterized accordingly.

In the second stage of the work, the wastewater was treated in the laboratory electrodialysis cell. In these experiments $250 \mathrm{~mL}$ of the wastewater was electrodialyzed at room temperature for $5 \mathrm{~h}$ with a constant current density of $20 \mathrm{~mA} \mathrm{~cm}^{-2}$. The wastewater sample was pumped through the central compartment of the laboratory electrodialysis cell (Figure 2). The two adjacent compartments, on the left and right sides of the central compartment, contained the solutions that received the ions transported from the wastewater sample in the central compartment. These solutions were initially set at $250 \mathrm{~mL}$ of $\mathrm{NaOH} 0.1 \mathrm{~mol} \mathrm{~L}^{-1}$ and as the ions were transported from the wastewater they became more concentrated. The solution that received the cations transported from the wastewater was called cationic solution and the solution that received the anions from the wastewater was called anionic solution. Since there was no contact between these solutions they could be analyzed separately. This allowed the identification of the cationic or anionic nature of the transported ions, as they were transported towards either the anode or the cathode. Finally, the last two compartments in the cell contained the electrodes and the electrode rinse solution $\left(\mathrm{NaOH} 1.0 \mathrm{~mol} \mathrm{~L}^{-1}\right)$, which also provided the counter ions transported to the adjacent compartments.

The last stage of the work was the wastewater treatment in the electrodialysis pilot plant. In these tests, both the concentrated and dilute compartments of the electrodialyzer were initially fed with $2 \mathrm{~L}$ of the wastewater samples. These solutions were pumped through the electrodialysis stack at a flow rate of $50 \mathrm{~L} \mathrm{~h}^{-1}$. During the experiment $(6 \mathrm{~h})$, ions were transported from the dilute stream towards the concentrated stream in the electrodialysis stack, according to the classical electrodialysis mechanism. This led to the production of two different solutions, one more dilute and another more concentrated than the initial solution. The electrodialysis experiments were carried out at both potentiostatic and galvanostatic control. In the potentiostatic experiments the total applied voltage was 5 $\mathrm{V}$ and in the galvanostatic experiments the current density was kept at $10 \mathrm{~mA} \mathrm{~cm}^{-2}$. The electrodes rinsing solution was $3 \%(\mathrm{~m} / \mathrm{m}) \mathrm{Na}_{2} \mathrm{SO}_{4}$.

\section{Results and Discussion}

\section{Wastewater characterization}

Figure 3 shows the obtained concentration of different elements in the wastewater as a function of time. The wastewater contaminants were mainly nickel, zinc, cooper, aluminum and iron. The wastewater also contained $\mathrm{Na}^{+}(1$ to $\left.10 \mathrm{mg} \mathrm{L}^{-1}\right), \mathrm{OH}^{-}(\mathrm{pH} 13)$ and $\mathrm{CN}^{-}$(at relatively high concentrations, up to $\left.1 \mathrm{~g} \mathrm{~L}^{-1}\right)$.

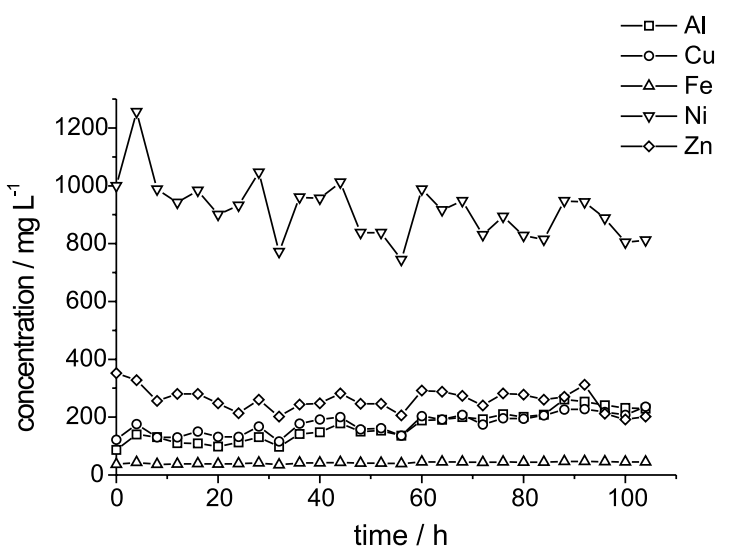

Figure 3. Variation of the concentrations of the metallic ions in the wastewater as a function of time.

These results suggest that the wastewater generated in the rinsing step of surface finishing processes varies in its chemical composition. This arises from many possible variations in the processes such as the number of parts being washed per time unity, the volume of fresh water fed to the system, the geometry of the parts that can lead to a higher or lower drag-out of the plating bath, and, to a minor extent, the bath composition. Furthermore, the simultaneous presence of different metallic ions in the 
effluent tends to bias the chemical analyses results. This is caused by the interference and the formation of stable complexes, due to the different possibilities of coordination between metallic cations and anionic ligands $\left(\mathrm{CN}^{-}, \mathrm{OH}^{-}\right)$. Table 1 presents the mean concentration values and standard deviation obtained from the analysis of a single wastewater sample only by atomic absorption spectroscopy. The relatively high standard deviation suggests that it is very difficult to get an accurate quantification of the ion concentrations in a single sample.

\section{Laboratory electrodialysis cell experiments}

Table 2 shows the initial concentration of the wastewater sample, as well as the amount of ions transported towards the cationic and anionic solutions after $5 \mathrm{~h}$ of experiment. As it can be seen, the metallic ions are predominantly in anionic form, since they are transported mainly towards the anionic solution. This behavior can be explained by the formation of negatively charged coordination complexes between the metallic ions and the $\mathrm{CN}^{-}$and $\mathrm{OH}^{-}$ligands. It can also be seen from Table 2 the relative mobility of the different ions in terms of percent extraction, as defined in Equation 1. The highest extraction was obtained for aluminum ions $(67.7 \%)$, while the iron ions had the lowest percent extraction $(16.0 \%)$. The reason for this behavior can be related to the relative mobility of these coordinated ions in solution, due to the differences in volume and electrical charge. Since the ligands are negatively charged, the complexes formed can have negative or positive charges, depending on the number of ligands. Moreover, negatively charged complexes can be associate with free metal cations, forming neutral complexes, which will not migrate under the electrical field (see later).

Figure 4 shows the variation in the conductivity during the experiment. As it could be expected, one can observe a decrease in the wastewater conductivity and a concomitant increase in the conductivity of both the anionic and cationic solutions. This clearly shows the reduction of total ion concentration in the wastewater being treated in the central compartment, and the increase in ion concentration in the cationic and anionic solutions. The cations transported are expected to be predominantly $\mathrm{Na}^{+}$, since they are not expected to coordinate in these conditions. Thus, they maintain their positive charge and are transported towards the cationic solution.

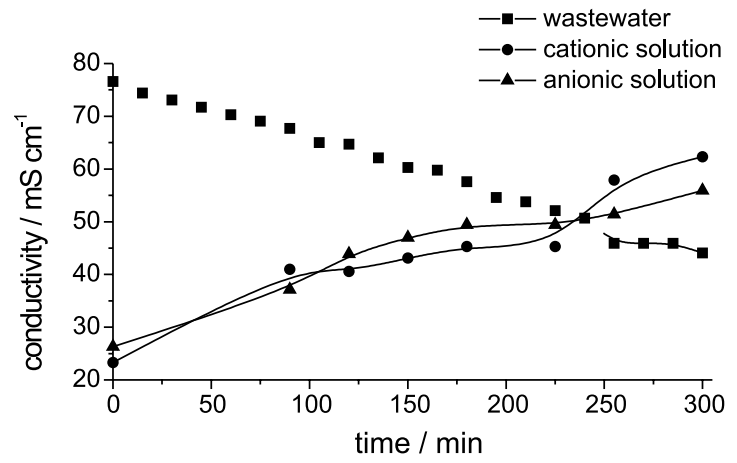

Figure 4. Variation of the conductivity of the different solutions in the laboratory electrodialysis cell as a function of the electrodialysis time.

Table 1. Data obtained on the chemical analysis of a sample of wastewater by atomic absorption spectroscopy

\begin{tabular}{lccccc}
\hline & $\mathrm{Zn}$ & $\mathrm{Fe}$ & $\mathrm{Cu}$ & $\mathrm{Ni}$ & $\mathrm{Al}$ \\
\hline mean concentration / $\mathrm{mg} \mathrm{L}^{-1}$ & 366.7 & 83.3 & 239.0 & 1212.4 & 251.2 \\
standard deviation / $\mathrm{mg} \mathrm{L}^{-1}$ & 66.7 & 5.4 & 20.8 & 97.1 & 5.5 \\
number of analyzes & 7 & 4 & 7 & 7 & 5 \\
\hline
\end{tabular}

Table 2. Concentrations of metallic ions in the original wastewater sample and in the cationic and anionic solutions after $5 \mathrm{~h}$ of treatment in the laboratory electrodialysis cell

\begin{tabular}{lccccc}
\hline & \multicolumn{3}{c}{ metallic ion } \\
\cline { 2 - 6 } & $\mathrm{Zn}$ & $\mathrm{Fe}$ & $\mathrm{Cu}$ & $\mathrm{Ni}$ & $\mathrm{Al}$ \\
\hline untreated wastewater & - & 82.0 & 244.3 & 1249.7 & 251.2 \\
concentration / $\mathrm{mg} \mathrm{L}^{-1}$ & - & 0.3 & 1.5 & 3.7 & 1.7 \\
cationic solution concentration / $\mathrm{mg} \mathrm{L}^{-1}$ & - & 12.8 & 120.1 & 502.3 & 168.3 \\
anionic solution concentration / $\mathrm{mg} \mathrm{L}^{-1}$ & - & $16.0 \%$ & $49.8 \%$ & $40.5 \%$ & $67.7 \%$ \\
percent extraction from the wastewater & & & & & \\
\hline
\end{tabular}




\section{Pilot plant experiments}

The behavior of the electrodialysis pilot plant system during the treatment of the wastewater samples is shown in Figures 5 and 6 for typical experiments under galvanostatic and potentiostatic control, respectively. In galvanostatic experiments a constant current is imposed to the system. As a consequence, a voltage is established across the electrodialysis stack, which is a function of the total resistance of the system. In this situation the electrodialysis stack can be compared to a group of series resistors, which includes the electrode reaction resistance, the electrode rinsing solution resistance, the membrane resistance and finally the concentrated and dilute solution resistances. As ion transport during the electrodialysis process produces a dilute solution flowing across the stack, the resistance continuously increases. This resistance increase is only partially compensated by the increasing conductivity of the concentrated solution. As a consequence, the total resistance increases in the electrodialysis stack. This effect, under galvanostatic control, is observed as the total voltage increase.

A slight voltage reduction after the beginning of the experiment is observed in Figure 5b. This is attributed to the heating of the solutions. After 40 min of electrodialysis, however, the total voltage (and thus the resistance) starts

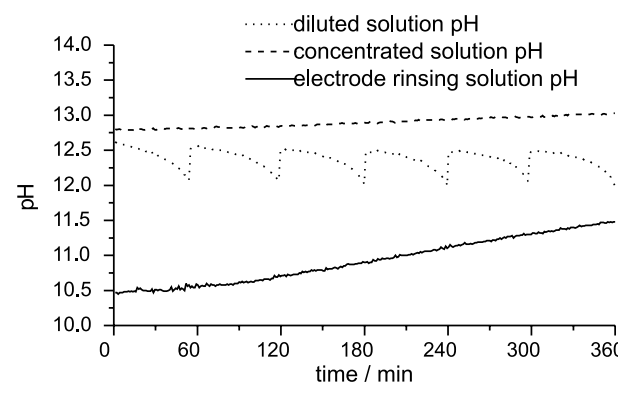

a)

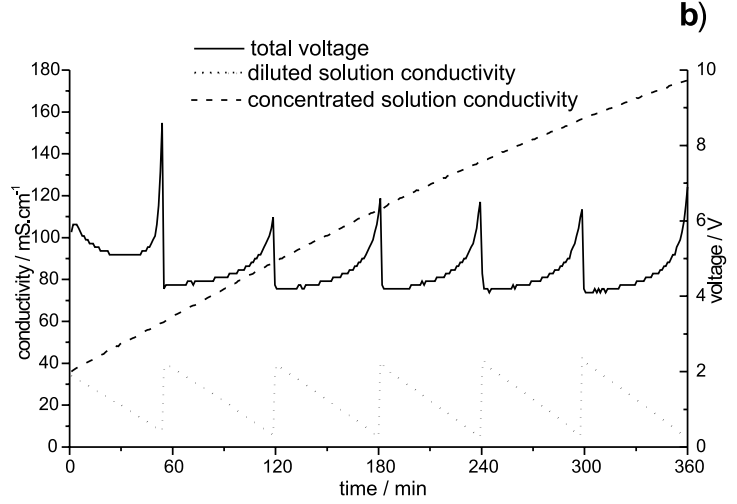

Figure 5. Variation of the main parameters during an electrodialysis experiment in the pilot plant system under galvanostatic control with a current density of $10 \mathrm{~mA} \mathrm{~cm}{ }^{-2}$. a) $\mathrm{pH}$ variation. b) conductivity and total voltage variation. to increase due to the depletion of ions in the dilute solution. As the voltage increases, there is a reduction in the dilute solution's conductivity (Figure $5 \mathrm{~b}$ ) and $\mathrm{pH}$ (Figure 5a). At this stage, $\mathrm{NaOH}$ was added to the dilute solution in order to avoid a big surge in voltage, leading to the occurrence of concentration polarization. ${ }^{6}$ The latter results in a voltage drop across the membrane-solution interfaces inside the stack, which can reach extremely high values producing the water split. As a consequence, the local $\mathrm{pH}$ can be drastically changed, resulting in membrane damage. As it can be seen in Figure 5, at the moment of $\mathrm{NaOH}$ addition there is an immediate increase in conductivity and $\mathrm{pH}$ as well as a voltage decrease. Aside from the problems concerning concentration polarization, the $\mathrm{pH}$ decrease in the solution dilute is also dangerous, due to the possibility of HCN formation. Since the main objective of the treatment is the extraction of heavy metal ions from the solution, consecutive addition of $\mathrm{NaOH}$ was carried out in order to complete the electrodialysis process, in an attempt to reach the lowest possible concentration of $\mathrm{Cu}, \mathrm{Ni}, \mathrm{Fe}, \mathrm{Zn}$ and $\mathrm{Al}$.
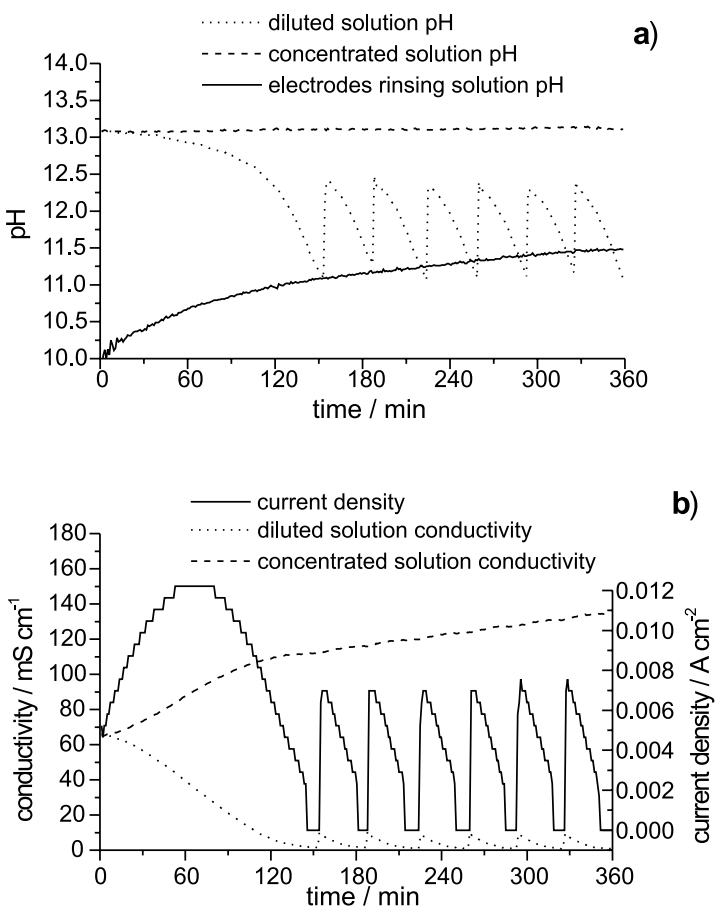

Figure 6. Variation of the main parameters during an electrodialysis experiment in the pilot plant system under potentiostatic control with a total imposed voltage of $5 \mathrm{~V}$. a) $\mathrm{pH}$ variation. b) conductivity and current density variation.

Similar behavior for experiments conducted under potentiostatic control was observed in Figure 6. However, instead of a voltage increase, ion depletion in the dilute solution led to a current decrease. The initial increase on 
the current is a result of the heating of the solutions, followed by a decrease due to the resistance increase. Also in this case, $\mathrm{NaOH}$ was repeatedly added to the dilute stream in order to avoid the danger of $\mathrm{HCN}$ formation due to the $\mathrm{pH}$ decrease.

Figures 5 and 6 also show that the conductivity of the concentrated solution continually increases throughout the experiment. Evidently, this conductivity increase is due to a general ion concentration increase, but this does not necessarily mean a high percent extraction of all the metallic ions. Instead, as it can be inferred from the consecutive addition of $\mathrm{NaOH}$ combined with the changes in the $\mathrm{pH}$ of the dilute solution, a significant amount of the ions transported to the concentrated solution could be $\mathrm{OH}^{-}, \mathrm{CN}^{-}$and $\mathrm{Na}^{+}$.

When using electrodialysis on wastewater treatment in an industrial level, considerations must be made in order to minimize the occurrence of such problems. One possibility, not investigated in this work, is the operation of the process in a continuous system instead of a batch system. In this case, a high ion depletion of the dilute solution is not necessary. Nevertheless, electrodialysis is used to maintain the ion concentration at a certain level, low enough to allow the reuse of the dilute solution as a rinsing water, and high enough to allow the steady operation of the electrodialysis device. The concentrated solution can then be treated in a conventional physicochemical process or, when suitable, reused to recompose the plating bath.

Besides the operational aspects discussed above, the metallic ion extraction efficiency must be measured in order to evaluate the feasibility of the process. The relative concentration of the ions in the concentrated and dilute solutions as a function of the electrodialysis time is shown in Figure 7 for an experiment under potentiostatic control. Efficiency can be evaluated using the relative concentration equation as follows:

$r c=\frac{\left(c_{t}-c_{0}\right)}{c_{0}} \times 100$

where $r c$ is the relative concentration, $c_{0}$ is the initial ion concentration and $c_{t}$ is the ion concentration at the time $t$.

As it can be seen in Figure $7 \mathrm{a}, \mathrm{Na}^{+}$is the metallic ion with the higher relative concentration. This is expected due to the addition of $\mathrm{NaOH}$ during the experiment. Moreover, $\mathrm{Na}^{+}$also has the higher dilution in the diluate, as shown in Figure 7b. This means that this ion has the best extraction efficiency in the conditions of this study. The other metallic ions have lower relative concentration, possibly due to the formation of less mobile cyano or hydroxo complexes (Ni, $\mathrm{Zn}, \mathrm{Cu}$ and $\mathrm{Fe}$ ) or aluminates (Al). As shown in Table 2, these ions are actually in anionic form. Other interesting features related to the relative concentration can be observed in Figure 7a. The highest values of relative concentration are obtained after about 2 $\mathrm{h}$ of experiment and thereafter this parameter begins to decrease. This effect is observed for $\mathrm{Zn}, \mathrm{Ni}$ and $\mathrm{Cu}$ (Al cannot be evaluated due to lack of data in intermediate times). Furthermore, Fe ions clearly show an opposite behavior since they do not concentrate in the concentrated solution. On the contrary, $\mathrm{Fe}$ concentration increases in the diluate. Figure 8 shows the absolute concentrations of the metallic ions in the concentrated solution. Once again, a)

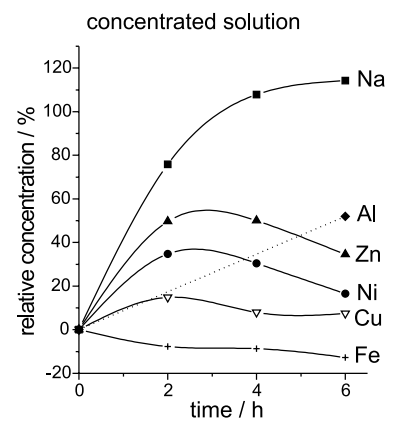

b)

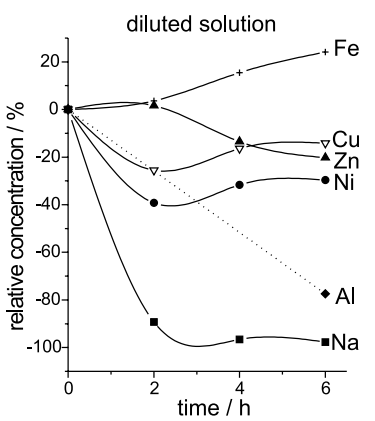

Figure 7. Relative concentrations of the metallic ions in the concentrated solution as a function of the electrodialysis time in an experiment under potentiostatic control.
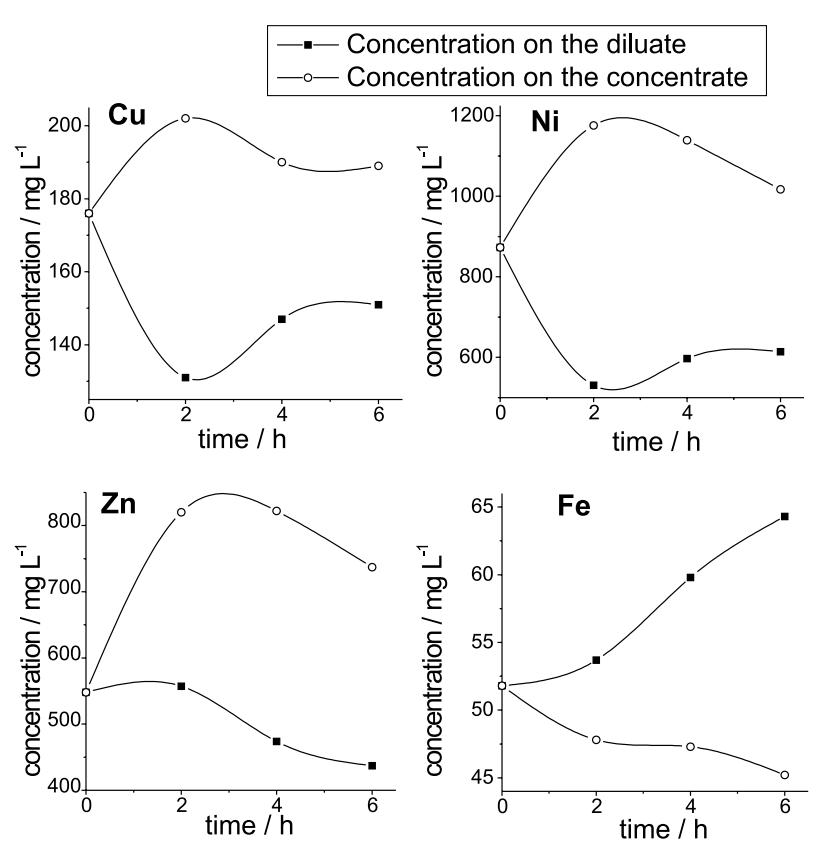

Figure 8. Absolute concentrations of the metallic ions in the concentrated and diluted solutions as a function of the electrodialysis time in an experiment under potentiostatic control. 
most of the ions have a maximal concentration at intermediate times.

These results can be understood considering the addition of $\mathrm{NaOH}$ in the dilute solution. The addition causes repetitive increase in the amounts of $\mathrm{Na}^{+}$and $\mathrm{OH}^{-}$ in the diluate. These ions are continually transported and accumulate in the concentrate. Since the other metallic ions are not added to the diluate during the experiment, a high gradient is established between their concentration in the concentrate and in the diluate. In the first hours of the experiment, the electrical field driving force is capable of transporting these ions (in anionic form) towards the concentrate. However, as the concentration gradient increases, any increment in the $\mathrm{Na}^{+}$and $\mathrm{OH}^{-}$concentration in the concentrate impels the metallic anions back to the diluate, by means of diffusion. This produces the decrease in the relative concentrations observed in Figure 7. The anomalous behavior of the Fe ions may be understood considering the presence of a relatively high amount of non-dissociated coordination complexes of iron, ${ }^{7}$ such as $\mathrm{Fe}\left[\mathrm{Fe}(\mathrm{CN})_{6}\right]$. These species have neutral charge, and as a consequence, would not migrate under the influence of the electrical field. This is in accordance with the relative low percent extraction observed for Fe on the laboratory electrodialysis cell experiments (see Table 2). The only driving force capable of transporting these neutral species is the concentration gradient progressively established between the concentrate and the diluate. Since the general ion concentration continuously increases in the concentrate, due to ion migration from the diluate, the neutral $\mathrm{Fe}$ complexes are "pushed" in the opposite direction by diffusion. As a consequence, Fe ions concentrate in the dilute solution.

In other words, the presence of two opposite effects leads to the appearance of a dynamic system. The ion transport by migration, combined with the transport constraints imposed by the permeability and selectivity properties of the membranes, leads to a continuous increase in the ion concentration in the concentrate. On the other hand, the concentration gradient progressively established between the concentrate and diluate solutions creates a diffusional ion flux in the opposite direction. This leads to a negative concentration rate for all the metallic species except the $\mathrm{Na}^{+}$, whose concentration in the diluate is corrected due to the $\mathrm{NaOH}$ addition. This can be observed after $2 \mathrm{~h}$ of experiment, in Figures 7 and 8. In the particular case of $\mathrm{Fe}$ ions, which are predominantly neutral and therefore are transported towards the concentrate by migration to a minor extent, this phenomenon is observed as a concentration increase in the diluate.

Some discrepancies, however, can be seen in Figure 8: since the diluate and concentrate volumes are equal, the concentration variations of each ion should be proportional in the concentrate and in the diluate. The asymmetries observed between the concentrate and diluate concentrations in comparison to the initial value are attributed to differences in the reproducibility of the results, associated mainly with the chemical analysis due to the complexity of the samples, as discussed above.

Since electrodialysis can be operated both in potentiostatic and galvanostatic modes, there is a need to choose the advantages of each process. Table 3 shows the percent extractions obtained in both conditions. Ni, $\mathrm{Zn}$ and $\mathrm{Cu}$ ions had a significantly higher extraction from the diluate under galvanostatic control. The opposite is observed for $\mathrm{Al}$ ions. The increase of the $\mathrm{Fe}$ concentration in the diluate was higher under potentiostatic control. Finally, Na showed a similar percent extraction in both conditions. This seems to indicate a better performance of the ion extraction under galvanostatic control. However, when choosing the best operation mode, other points must be considered. Potentiostatic control can be safer to operate in the sense that it does not permit the development of high voltages across the stack, when the ion concentration in the diluate is excessively low. This avoids the occurrence of concentration polarization and the problems related to it.

Considerations about the economical aspects of the process and commercial accessibility of the equipment are frequently decisive when scaling up a pilot system to industrial operation. These aspects are going to be evaluated on the next steps of this work. Nevertheless, other technical points must be raised. Of special interest, when employing electrodialysis on the treatment of metal finishing wastewater, is the reuse of spent wastewater, obtained as a diluate in the electrodialysis cell. The other interest is the recovery of metal ions as a concentrated

Table 3. Percent extraction of the different metallic ions after $6 \mathrm{~h}$ of treatment in the electrodialysis pilot plant under potentiostatic and galvanostatic control

\begin{tabular}{lcccccc}
\hline & \multicolumn{5}{c}{ Percent extraction / \% } \\
\cline { 2 - 7 } & $\mathrm{Zn}$ & $\mathrm{Fe}$ & $\mathrm{Cu}$ & $\mathrm{Ni}$ & $\mathrm{Al}$ & $\mathrm{Na}$ \\
\hline Potentiostatic control & 20.3 & -24.1 & 14.2 & 29.7 & 77.4 & 97.8 \\
Galvanostatic control & 68.5 & -9.6 & 23.5 & 46.0 & 46.7 & 90.6 \\
\hline
\end{tabular}


brine, which can be used to replenish the plating bath. However, this can only be accomplished when no bath contaminants are present or when these contaminants are not concentrated from the wastewater.

The wastewater used in this work contains relatively high amounts of $\mathrm{Al}$ ions, which are bath contaminants generated during the plating process due to chemical attack of the parts being plated. If electrodialysis is proposed to recycle the wastewater as rinse-water and to concentrate the metal ions as a concentrated brine to recompose the plating bath, care must be taken to avoid the concentration of this contaminant. The results showed that $\mathrm{Al}$ ions have a high relative concentration. This means that the concentrated brine cannot be used to recompose the bath, unless modifications to the electrodialysis system are made to avoid $\mathrm{Al}$ concentration. These modifications may include changes to the membrane selectivity or chemical complexation of the $\mathrm{Al}$ ions. Nevertheless, the process can be used on an industrial level to recycle the wastewater as rinse-water, and to concentrate the solution to be discharged, thus decreasing the volume of wastewater to be treated by conventional chemical processes.

\section{Final Remarks}

In the wastewater studied, most of the metallic ions have an anionic nature, which implies transport across the anion-selective membrane. Hence, special attention must be paid in order to choose the best membrane configuration for the electrodialysis stack, in particular related to the characteristics of the anion-selective membranes. The addition of $\mathrm{NaOH}$ in the batch operation of the electrodialysis pilot plant was necessary for $\mathrm{pH}$ correction and for keeping voltage and current within the desired range. The highest ion concentration was obtained between 2 and $3 \mathrm{~h}$. After that, process efficiency decreased due to the high amounts of $\mathrm{NaOH}$ transported to the concentrate. Iron showed an unexpected behavior, being concentrated in the diluate. This can possibly be explained due to the neutral nature of $\mathrm{Fe}$ complexes.

In the scale-up of the system to industrial operation, two important points must be considered. First of all, the continuous operation of the process instead of a batch system is possibly more advantageous, due to the problems related to the high ion depletion in the diluate. Finally, the concentration of $\mathrm{Al}$ as a contaminant restricts the possibility of using the concentrate to recompose the plating bath.

\section{Acknowledgements}

The authors wish to thank Andreas Stihl Moto-serras Ltda and FAPERGS for the financial support. They also wish to thank Joe da Costa, the University of Queensland, and Juliana Duku, Queen Mary, University of London, for helpful suggestions.

\section{References}

1. Bernardes, A.M.; Dalla Costa, R. F.; Fallavena, V.L.V.; Rodrigues, M.A.S.; Trevisan, M.D.; Zoppas Ferreira, J.; Metal Finishing 2000, 98, 52.

2. Ganni, H.H.; Brezovec, P.J. In Electrochemical Technology Applied to Environmental Problems; Brooman, E.W.; Hammel, C.; Fenton, J.M., eds.; Proceedings of the Electrochemical Society Inc.: Reno, 1995.

3. Audinos, R. In Separation and Purification Technology; Li, N.N.; Calo, J.M., eds.; Marcel Dekker: New York, 1992, ch. 8.

4. Blackburn, J.W.; J. Air Waste Manage. 1999, 49, 934; Cattoir, S.; Smets, D.; Rahier, A.; Desalination, 1999, 121, 123; Korngold, E.; Koch, K.; Strathmann, H.; Desalination, 1978, 24, 129.

5. Paquay, E.; Clarinval, A.-M.; Delvaux, A.; Degrez, M.; Hurwitz, H.D.; Chem. Eng. J. 2000, 79, 197; Li, C.L.; Zhao, H.X.; Tsuru, T.; Zhou, D.; Matsumura, M.; J. Memb. Sci. 1999, 157, 241; Purdy, G.; Zawodzinski, C.; Smith, B.; Smith, W.H.; Sep. Sci. Technol. 1995, 30, 1951.

6. Leitz, F.B.; Desalination, 1986, 59, 381; Audinos, R.; Electrochim. Acta. 1980, 25, 405.

7. Vogel, A.; Química Analítica Qualitativa, $5^{\text {th }}$ ed., Mestre Jou: São Paulo, 1981.

Received: January 17, 2002

Published on the web: August 2, 2002 